\title{
Holocene forest development and maintenance on different substrates in the Klamath Mountains, northern California, USA
}

\author{
Christy E. Briles, ${ }^{1,5}$ Cathy Whitlock, ${ }^{2}$ Carl N. Skinner, ${ }^{3}$ and Jerry Mohr ${ }^{4}$ \\ ${ }^{1}$ Palynology Laboratory, Texas A\&M University, College Station, Texas 77843-4352 USA \\ ${ }^{2}$ Department of Earth Sciences, Montana State University, Bozeman, Montana 59717 USA \\ ${ }^{3}$ USDA Forest Service, Pacific Southwest Research Station, Redding, California 96002 USA \\ ${ }^{4}$ College of Forestry, Oregon State University, Corvallis, Oregon 97331 USA
}

\begin{abstract}
The influence of substrate on long-term vegetation dynamics has received little attention, and yet nutrient-limited ecosystems have some of the highest levels of endemism in the world. The diverse geology of the Klamath Mountains of northern California (USA) allows examination of the long-term influence of edaphic constraints in subalpine forests through a comparison of vegetation histories between nutrient-limited ultramafic substrates and terrain that is more fertile. Pollen and charcoal records spanning up to 15000 years from ultramafic settings reveal a distinctly different vegetation history compared to other soil types. In non-ultramafic settings, the dominant trees and shrubs shifted in elevation in response to Holocene climate variations resulting in compositional and structural changes, whereas on ultramafic substrates changes were primarily structural, not compositional. Fire activity was similar through most of the Holocene with the exception of declines over the last 4000 years on ultramafic substrates, likely due to the reduction of understory fuels and cooler wetter conditions than in the middle Holocene. These results suggest that the tree and shrub distributions were more responsive to past climate changes on non-ultramafic substrates compared to those on ultramafic substrates. The combination of these dynamics may help explain high levels of plant diversity in the Klamath Mountains and provide insights for managing these complex ecosystems.
\end{abstract}

Key words: biodiversity controls; climate change; geoecology; Holocene; Klamath Mountains, California (USA); substrates; vegetation and fire history.

\section{INTRODUCTION}

The Klamath Mountains of northern California, USA, are home to one of the most diverse temperate conifer forests in the world, with 39 conifer species including seven endemics (DellaSala et al. 1999, Ricketts et al. 1999). Explanations for the high diversity, outlined by Whittaker (1960), have focused on (1) the region's complex geology and its influence on soil fertility (Coleman and Kruckeberg 1999, Kruckeberg 2002); (2) the steep elevational gradients of the Klamath region (sea level to $2750 \mathrm{~m}$ elevation) that drive sharp vegetation changes from west to east, north to south, and along mountain slopes (DellaSala et al. 1999); (3) a spatially complex disturbance regime, resulting from strong environmental gradients (Skinner et al. 2006); and (4) the region's possible role as a long-term refugium for plants that have survived climate changes of the late Cenozoic (Axelrod 1988).

This study examines one of the possible explanations for the diversity, namely, the interacting effects of

Manuscript received 29 September 2009; revised 4 August 2010; accepted 16 August 2010. Corresponding Editor: K. D. Woods.

${ }^{5}$ Present address: Geography and Environmental Science, Monash University, Clayton Campus, Melbourne, Australia 3800. E-mail: christybriles@gmail.com geology and climate change on the long-term history of the vegetation. The patchiness of unusual ultramafic soils in the Klamath Mountains today influences the distribution of plant species and creates unique plant communities. Areas underlain by serpentinite, peridotite, and other ultramafic rock types are limited in calcium and potassium and high in toxic elements, including magnesium and nickel (Kruckeberg 1984, Proctor 1990, Alexander et al. 2007), resulting in harsh soils and sparse plant communities with many endemic species (see Plate 1).

To assess the influence of substrate on the Holocene vegetation history of the Klamath Mountains, we examined pollen and charcoal data from sediment cores of eight lakes in subalpine forests for the last 15000 years. Three sites are in watersheds composed of ultramafic rock types and five sites are located in nonultramafic geological settings (see Fig. 1). The ecological response to past climate changes was described using independent proxies of climate change from northern California derived from (1) sea-surface temperature reconstructions from alkenone (highly resistant ketones produced by phytoplankton) data from an ocean core (ODP 1019; Ocean Drilling Program, available online) ${ }^{6}$

${ }^{6}\langle$ http://www-odp.tamu.edu/ $\rangle$ 


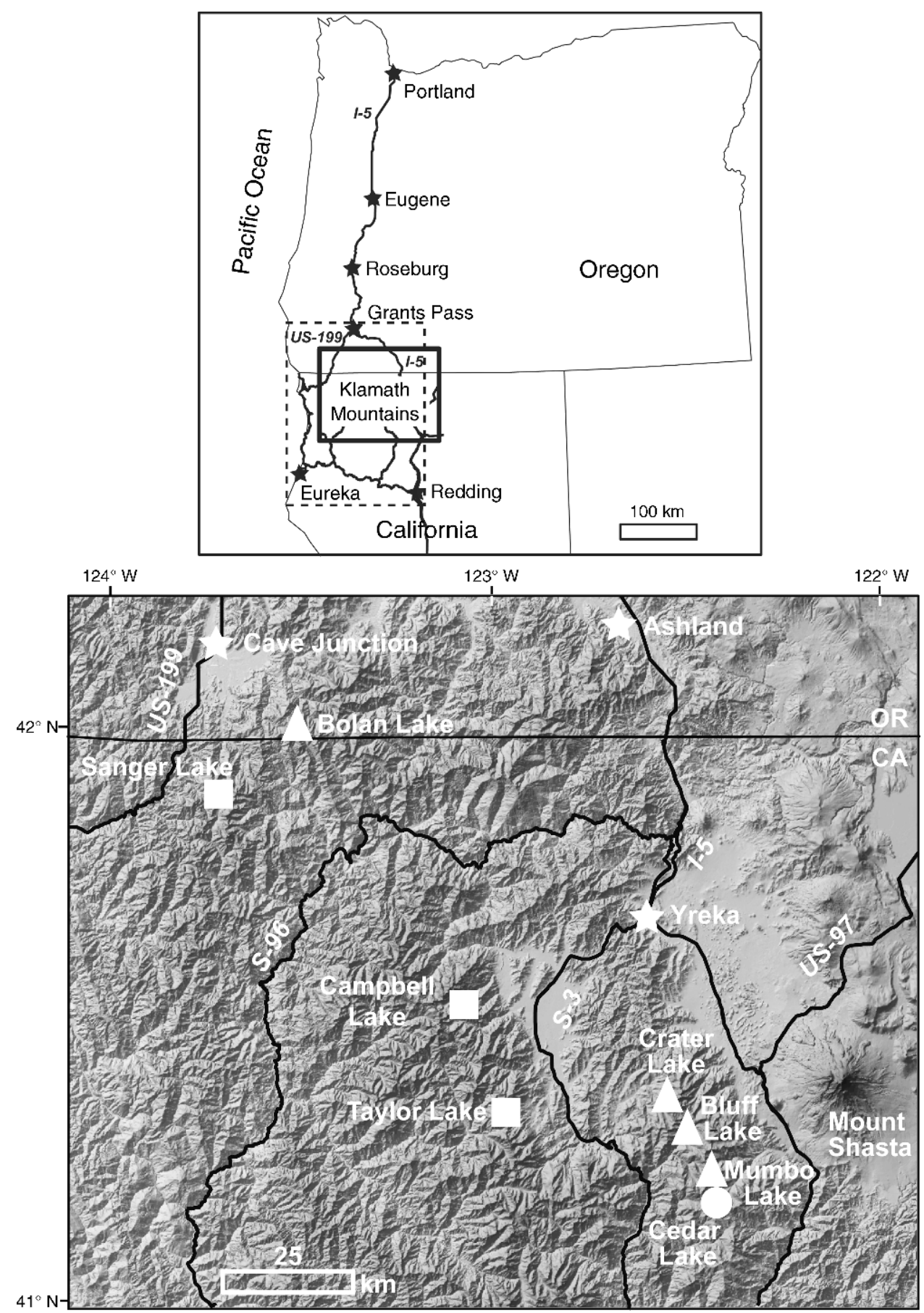

FIG. 1. The Klamath Mountains, northern California, USA (dashed outline), study area (solid outline), and study sites. Key to symbols: triangles, lakes with existing published records; circles, lakes with existing unpublished records; squares, new lakes presented here in detail.

off the coast of Oregon (Barron et al. 2003), (2) temperature and terrestrial biomass variations based on $\delta^{18} \mathrm{O}$ and $\delta^{13} \mathrm{O}$ data from speleothem (cave formation) records collected at Oregon Cave National Monument in southwestern Oregon (Vacco et al. 2005), and (3) largescale modeled circulation features provided by paleo- climate model simulations of western North America for the last 15000 years (Bartlein et al. 1998).

Several ecological (i.e., Grime et al. 2000, 2008) and paleoecological studies (Brubaker 1975, Whitlock 1993, Oswald et al. 2003) have found limited plant response to climate change on infertile substrates. Therefore, we 
hypothesized that forests on infertile ultramafic soils in the Klamath Mountains would also experience less compositional change than those on substrates that are more fertile during periods of Holocene climate change. Alternatively, if edaphic stresses imposed by ultramafic substrates were less limiting, climate may have been the primary driver of Holocene forest change on all substrates in the Klamath Mountains. On all substrates, we expected climate and fuel conditions to drive fire activity (Marlon et al. 2006, Skinner et al. 2006).

Our goal was to address the following questions:

1) What was the Holocene vegetation and fire history of the Klamath Mountains? Given the geological complexity of the region, we were specifically interested in the roles of past climate change and edaphic conditions in shaping the forests.

2) How does the Holocene paleoecology of the Klamath region help us understand the controls on forest biodiversity and its management in the face of future climate change?

\section{Site Descriptions}

New sediment cores from Taylor, Campbell, and Cedar lakes, and published data from Sanger, Bolan, Bluff, Crater, and Mumbo lakes (Mohr et al. 2000, Briles et al. 2005, 2008, Daniels et al. 2005) were used to reconstruct the vegetation and fire history of the Klamath Mountains (see Fig. 1). Bluff, Crater, and Cedar lakes are located on the Trinity Ultramafic Sheet in the southeastern Klamath Mountains (Irwin 1981). The other five sites, Taylor, Campbell, Bolan, Sanger, and Mumbo lakes, are on primarily granitic and metamorphic-derived soils (for detailed site descriptions see Appendix A).

Except for substrate differences, the eight sites have similar environmental characteristics. All are located in late-Pleistocene cirque basins between 1547 and $2288 \mathrm{~m}$ elevation. The modern climate is characterized by cool winters (average temperatures for winter ranging between $-4.6^{\circ} \mathrm{C}$ and $0^{\circ} \mathrm{C}$ ) and mild summers (average temperatures for summer ranging between $14^{\circ} \mathrm{C}$ and $16^{\circ} \mathrm{C}$; see Appendix A). Half of the annual precipitation $(\sim 1100 \mathrm{~mm})$ falls in winter $(\sim 500-550 \mathrm{~mm})$ as snow and $\sim 15 \%$ in summer $(55-60 \mathrm{~mm})$ as rain from thunderstorms (P. J. Bartlein and S. Shafer, unpublished data).

The sites lie in the present-day Abies concolor (white fir) vegetation zone (1300-1900 m elevation) and its transition with the higher Abies magnifica var. shastensis (Shasta red fir) vegetation zone (1500-2200 m elevation) (Franklin and Dyrness 1988, Sawyer and Thornburgh 1988; see Appendix A for dominant tree species at each site). All botanical nomenclature is based on Hickman (1993). The ultramafic sites today support open forests dominated by Pinus jeffreyi (Jeffrey pine) and Calocedrus decurrens (incense cedar), with a shrub understory of Quercus vaccinifolia (huckleberry oak), Arctostaphylos spp. (manzanita), and diverse herbs (Alexander et al. 2007). Non-ultramafic sites have better-developed soils with higher soil permeability, $\mathrm{pH}$, and fertility. The dominant plant species at the non-ultramafic sites include Abies concolor, Abies magnifica var. shastensis, Pseudotsuga menziesii (Douglas-fir), and Pinus monticola (western white pine), and forests are closed (Kruckeburg 2002, Alexander et al. 2007). Tsuga mertensiana (mountain hemlock) becomes a more dominant species on non-ultramafic substrates above $1900 \mathrm{~m}$ elevation, while Pinus lambertiana (sugar pine) occurs in minor amounts between 800 and 1500 m elevation (Jimerson et al. 1995, Barbour et al. 2007).

Fire is a dominant disturbance agent, influencing community structure and dynamics in the Klamath Mountains today (Agee 1993, 2007). The mean fire return interval in the Abies concolor zone ranges between 10 and 64 years (Skinner et al. 2006). Abies concolor, A. magnifica var. shastensis, and $T$. mertensiana are firesensitive when young, but thick-barked mature trees are more fire tolerant. Pinus monticola is also fire-sensitive, but is a seral species that relies on fire to open the canopy. Fires in the Abies concolor zone tend to be lowto-moderate intensity surface fires, but crown fires may occur in densely forested areas with ample ladder fuels (Burns and Honkala 1990, Skinner et al. 2006). Downslope of the Abies concolor zone, in forests dominated by Pinus ponderosa (ponderosa pine), Pseudotsuga, and $C$. decurrens, mixed-severity fires occur on average every 6-22 years. In the higher Tsuga mertensiana zone $(>2200 \mathrm{~m})$, fires are less frequent $(>100$ years return time), and though often of low-moderate intensity, the sensitivity of vegetation to fires results in higher severity effects (Taylor and Skinner 1998, 2003). There is little statistical difference in fire regimes between substrates, but fire activity is strongly dependent on the continuity of the understory vegetation (Skinner 2003, Whitlock et al. 2004, Skinner et al. 2006).

\section{Methods}

We retrieved long sediment cores from new sites (Taylor, Campbell, and Cedar Lakes) using a modified Livingstone piston sampler (Wright et al. 1983) and short cores $<1 \mathrm{~m}$ using a Klein piston corer, from an anchored platform in the deepest water. Recovered core lengths were $5.86 \mathrm{~m}$ at Taylor Lake, $5.20 \mathrm{~m}$ at Campbell Lake, and $3.67 \mathrm{~m}$ at Cedar Lake. Cores were wrapped in cellophane and aluminum foil and transported back to the laboratory where they were refrigerated. Cores were cut in half, described, and subsampled at 1-cm intervals.

Age-depth models were developed for new and published records using new radiocarbon calibration information (Reimer et al. 2004) and modeling techniques (Higuera et al. 2008). For Campbell, Taylor, and Cedar lakes, ${ }^{14} \mathrm{C}$ AMS (accelerator mass spectrometry) dates were obtained on plant macrofossils (seed, twigs, and leaves) and sediment (only where necessary) from the long cores. Sediments from short cores were dated using ${ }^{210} \mathrm{~Pb}$. We calibrated the radiocarbon ages using Calib 5.0.2 software (Stuiver et al. 2005), and age-depth 
models were constructed with a cubic smoothing spline and Monte Carlo approach that allowed each date to influence the age model through the probability density function of the calibrated age (Reimer et al. 2004, Briles et al. 2008, Higuera et al. 2008). We used previously published age-depth models for Bolan and Sanger lakes (Briles et al. 2008).

We prepared pollen samples of $1 \mathrm{~cm}^{3}$ volume following methods of Bennett and Willis (2002). Sample intervals ranged from 50 to 300 years. We identified pollen grains to the lowest taxonomic level possible at magnifications of $500 \times$ and $1250 \times$, and counted at least 300 terrestrial grains and at least 100 non-Pinus grains per sample. The reconstruction of past vegetation was based on the interpretation of changes in pollen percentages and pollen accumulation rates (PAR; grains $\left.\cdot \mathrm{cm}^{-2} \cdot \mathrm{yr}^{-1}\right)$. The pollen-percentage records were divided into zones by use of a constrained cluster analysis (CONISS; Grimm 1988), and represent compositional and/or structural changes in the forest.

Two factors limit the resolution of paleoecological studies in the Klamath region. First, the pollen of many plant taxa cannot be identified below the level of genus (e.g., Abies, Amelanchier), subgenus (e.g., Diploxylontype [yellow] or Haploxylon-type [white] Pinus), or family level (e.g., Cupressaceae), and this hinders assignment of species in the past. Plant macrofossils found in sediment and charcoal residues provided species identification in cases where pollen could not, and confirmed local presence (Jackson et al. 1997). Inference from modern phytogeography also allowed us to narrow down the species likely represented in some samples (Burns and Honkala 1990, Hickman 1993). The second limitation results from different pollen dispersal methods among species. Several important taxa in the Klamath Mountains are animal- or insect-pollinated, and their pollen very rarely makes it into lake sediments. For example, the insect-pollinated Ericaceae regionally includes 26 genera and hundreds of species, some of which are limited to ultramafic substrates (e.g., Arctostaphylos klamathensis). The absence of pollen evidence for these taxa constrains our ability to describe completely past species diversity. In contrast, some wind-pollinated species, such as those in the genus Pinus, are among the most prolific producers of pollen and overrepresented in the pollen record compared to the actual abundance of those individuals in the forest.

We extracted charcoal particles $(>125 \mu \mathrm{m})$ from $1-\mathrm{cm}^{3}$ samples taken at contiguous 1-cm intervals with standard sieving methods (Whitlock and Larsen 2002). The size fraction provided a watershed (local) signal of fire. Conversion of charcoal concentration data to charcoal accumulation rates (CHAR; particles $\left.\cdot \mathrm{cm}^{-2} \cdot \mathrm{yr}^{-1}\right) \mathrm{em}-$ ployed CharAnalysis software (Briles et al. 2008, Higuera et al. 2008), distinguishing long-term trends (background CHAR) from short-term peaks in CHAR. Charcoal peaks represent one or more fires occurring during the sample interval, and the time span between peaks identifies the local fire-episode return interval $(\mathrm{FeI})$. In order to compare the charcoal time series from the eight sites, the charcoal concentrations and deposition rates were binned at 50-yr intervals (based on slowest deposition rate) before converting the data to CHAR. Standardizing all records in this way produced different results from those previously published (Mohr et al. 2000, Briles et al. 2005, 2008, Daniels et al. 2005). Mumbo Lake had unusually slow deposition rates $(>80 \mathrm{yr} / \mathrm{cm})$ and was not included in the regional analysis. A locally weighted 700yr mean robust to outliers was used to define background CHAR and peaks (fire episodes). FeIs were calculated based on the time between individual fire episodes and summarized by smoothing the time intervals with a tricubic locally weighted regression (1000-yr window; Cleveland 1979) in order to display long-term trends in fire activity. FeIs based on charcoal data potentially represent more than one fire year, making it difficult to compare paleo-FeIs with mean fire-return intervals estimated from fire-scarred tree-rings or observational fire data (Whitlock et al. 2004).

\section{Results AND Discussion}

\section{Question 1: vegetation, fire, and climate history of the Klamath Mountains}

The eight records considered together (Figs. 2a-g and 4) help clarify the environmental history of subalpine forests in northern California, specifically those on unique soil types. Age determinations based on ${ }^{210} \mathrm{~Pb}$ and ${ }^{14} \mathrm{C}$ AMS dates and tephrochronology (volcanic ash dating) (Appendices B and C) provide a time line for environmental change. Most sites separated easily by substrate type based on their pollen spectra. However, Mumbo Lake (Fig. 2d) lies in a watershed primarily underlain by diorite bedrock with extensive ultramafic outcrops nearby, and the site likely captures pollen from both substrate types. The fire history reconstructions of individual sites are published (Mohr et al. 2000, Briles et al. 2005, 2008, Briles 2008); here we describe the composite records of FeIs (Fig. 3).

Late-glacial period $(15000-11700 \mathrm{cal}$ yr BP).-At non-ultramafic sites (Taylor, Campbell, Bolan, and Sanger lakes; Fig. 2 e-h) the landscape was characterized by a subalpine parkland in the full-glacial period prior to 15000 calendar years before present (cal yr BP; see Briles et al. 2005), based on high percentages of Artemisia and Poaceae $(\sim 15 \%)$ and moderate percentages of conifer species (Haploxylon Pinus [65\%] and Tsuga mertensiana [5\%]). A significant change in plant composition and structure occurred after 15000 cal yr BP with the development of a mixed-conifer forest as indicated by the pollen percentages of Abies (likely $A$. concolor and A. magnifica var. shastensis; 5-10\%), Tsuga mertensiana (5-10\%), Pseudotsuga menziesii (5-10\%; northern sites only), and Haploxylon-type Pinus (probably P. monticola; 60-80\%), and low percentages of Artemisia and herbaceous species. Paleorecords for ultramafic sites (Cedar, Bluff, and Crater lakes; Fig. 


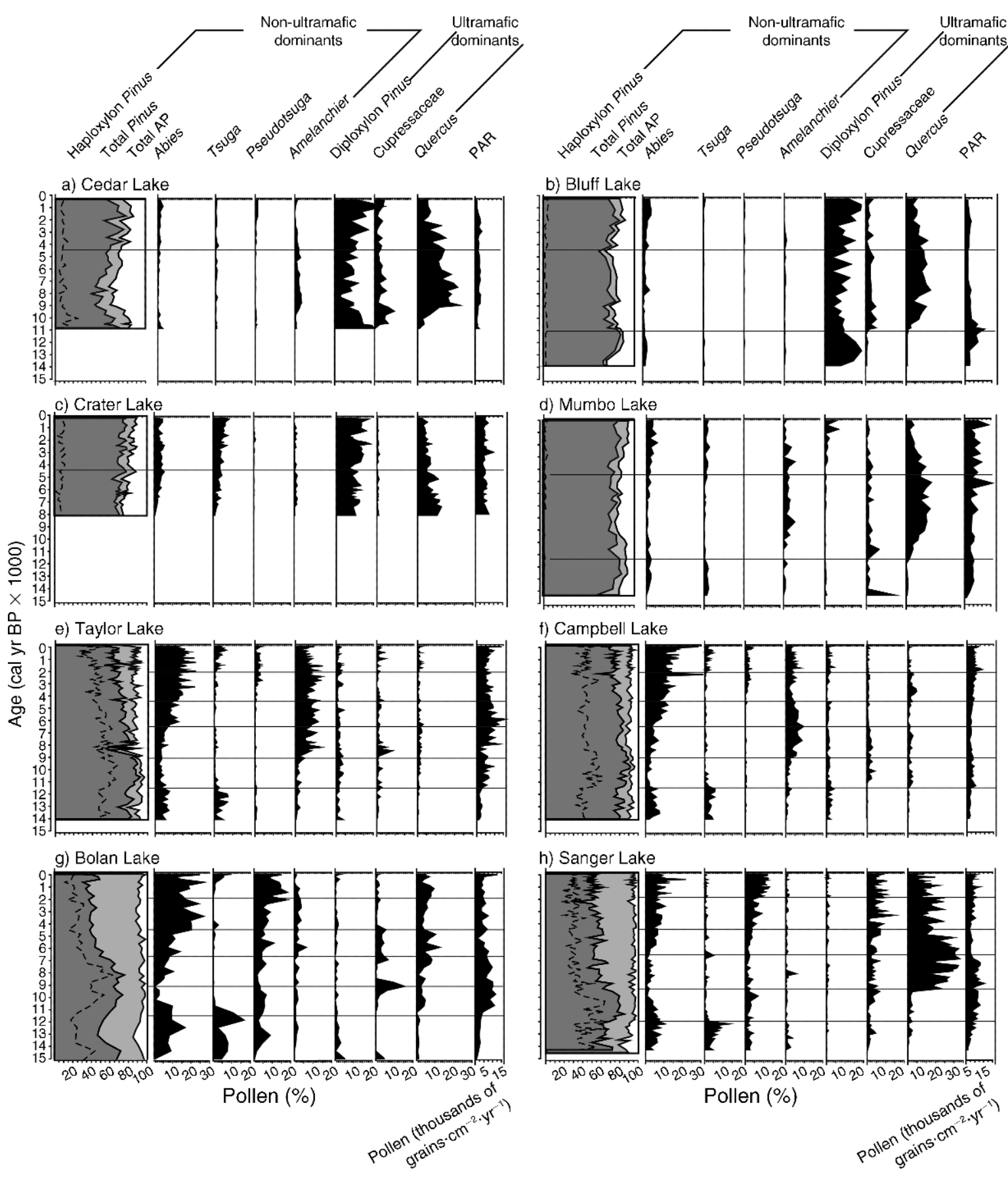

FIG. 2. Pollen percentages and total pollen accumulation rates (PAR) for non-ultramafic sites (Taylor, Campbell, Bolan, Sanger, and Mumbo lakes) and ultramafic sites (Bluff, Cedar, and Crater lakes). Horizontal lines show zone boundaries. AP is arboreal pollen.

2a-c) do not extend past 15000 cal yr BP; however after 15000 cal $\mathrm{yr}$ BP, they record high percentages of Diploxylon-type Pinus and herbaceous species (60$70 \%$ and $10-20 \%$, respectively). The abundance of Diploxylon-type Pinus and herbaceous pollen through the late-glacial period imply parkland. Charcoal accumulation rates are low and few fires are recorded at any of the sites, suggesting that sparse fuels, high humidity, or lack of ignitions limited fire activity during the lateglacial period.

The vegetation reconstruction from all sites after 15000 cal yr BP is consistent with warmer wetter conditions than in the full-glacial period. During this time, summer insolation was increasing from low levels, 


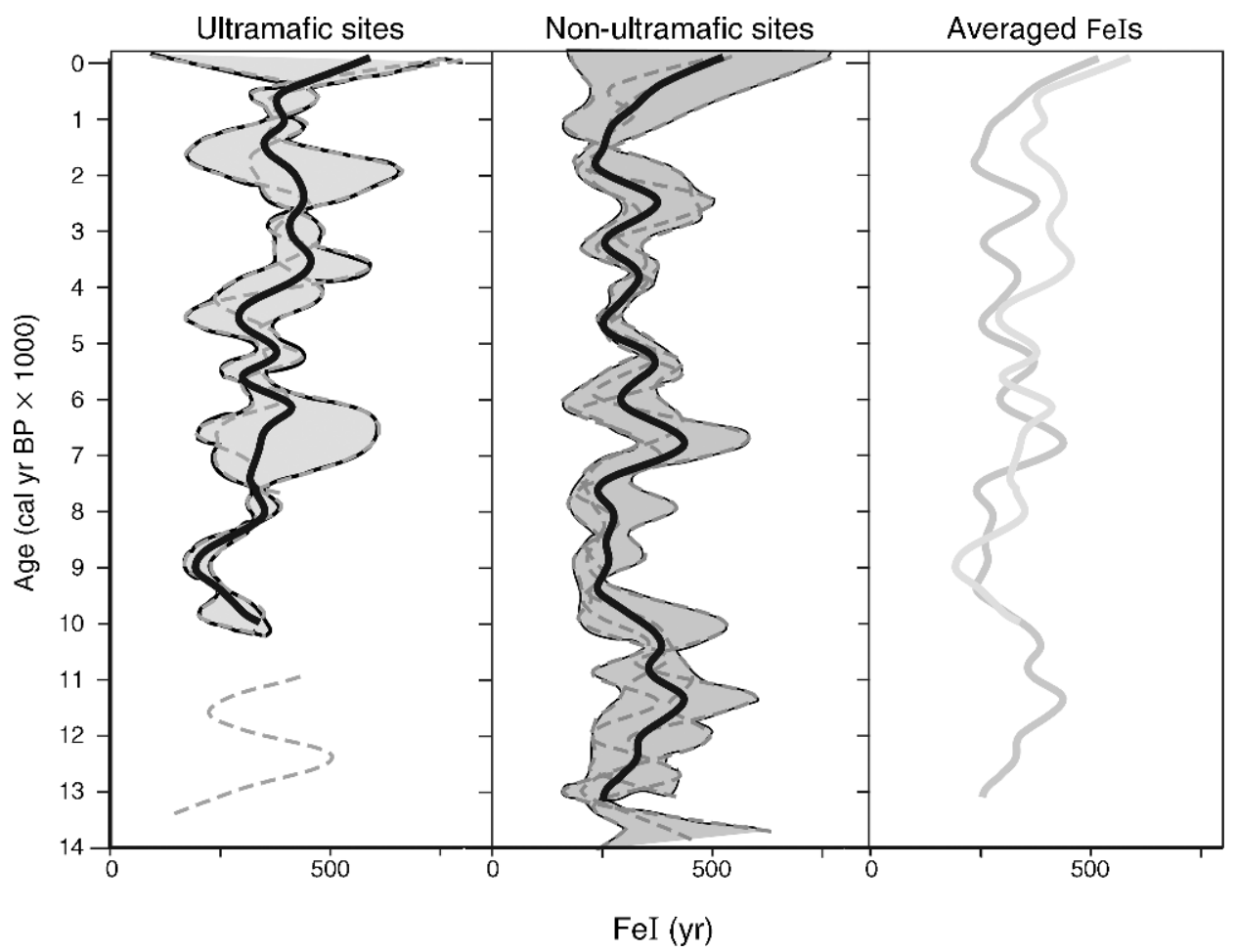

FIG. 3. Mean fire-episode return intervals (FeIs, years between fires) (heavy black line) for sites on ultramafic (dashed light gray) and non-ultramafic (dashed dark gray) sites based on charcoal concentration data converted to charcoal accumulation rates (CHAR) and analyzed using CharAnalysis software (Higuera et al. 2008; see Briles et al. [2008] and Mohr et al. [2008] for Bolan, Sanger, Bluff, and Crater lakes and Briles [2008] for Campbell, Taylor, and Cedar lake charcoal results). Upper and lower FeIs are shaded to show the range of variability within substrate type. FeIs were averaged to display regional trends in fire occurrence on each substrate type.

causing increased continental heating and warmer conditions (Bartlein et al. 1998). Paleoclimate model simulations for 14000 years ago suggest that a northward shift in the jet stream brought wetter conditions to the Pacific Northwest. Sea surface temperatures (SST) were $1-2^{\circ} \mathrm{C}$ less than present off the coast of northern California between 15000 and $13000 \mathrm{cal}$ yr BP, but warmer than the full-glacial period (Barron et al. 2003).

During the Younger Dryas chronozone (1290011700 cal yr BP), pollen percentages of Abies and $T$. mertensiana increase (to $10-15 \%$ ) on non-ultramafic substrates at northern sites (i.e., Bolan and Sanger lakes) indicating a more closed forest of mesophytic species. Southern sites on non-ultramafic substrates show no change from before. On ultramafic substrates, Diploxylon-type Pinus pollen percentages remain unchanged from before indicating little vegetation change during the abrupt climate event. The longest fire-free periods occurred during this time (FeIs of 450 years), possibly due to wetter conditions and/or fewer ignitions than before. An abrupt cooling of $3^{\circ} \mathrm{C}$ during the Younger Dryas chronozone has been inferred from $\delta^{18} \mathrm{O}$ data at Oregon Caves (Vacco et al. 2005) and from SST estimates (Fig. 4; Barron et al. 2003). In addition, the Oregon Caves record indicates increasing biomass, suggesting more forest cover (Fig. 4). While ocean temperatures were colder than before during the Younger Dryas chronozone, land conditions during the growing season were likely warm due to increasing summer insolation and may have favored mesophytic as opposed to cold-tolerant species. The late-glacial was a period of structural vegetation change from subalpine parkland to closed forests on non-ultramafic substrates; however the open forests on ultramafic substrates showed little compositional change during this time, even though the climate was becoming wetter and possibly warmer than in the full-glacial period.

Early and middle Holocene (ca. 11700 to $4500 \mathrm{cal} \mathrm{yr}$ $B P$ ).-On non-ultramafic substrates, between ca.11 700 and $11000 \mathrm{cal}$ yr BP, there are sharp declines in the pollen percentages of $T$. mertensiana, $P$. menziesii, and species of Abies (to $>1 \%,>1 \%$, and $>5 \%$, respectively), and an increase in Haploxylon-type Pinus (probably $P$. monticola and $P$. lambertiana), Cupressaceae, and Quercus vaccinifolia (up to $80+\%, 2-10 \%$, and 10-30\% at northern sites, respectively). Ultramafic sites show declining percentages of $P$. jeffreyi (to $>70 \%$ ) and an increase in Cupressaceae and $Q$. vaccinifolia (up to $10 \%$ and 20\%, respectively). During this time, higher-thanpresent summer insolation led to the expansion and intensification of the northeastern Pacific subtropical 


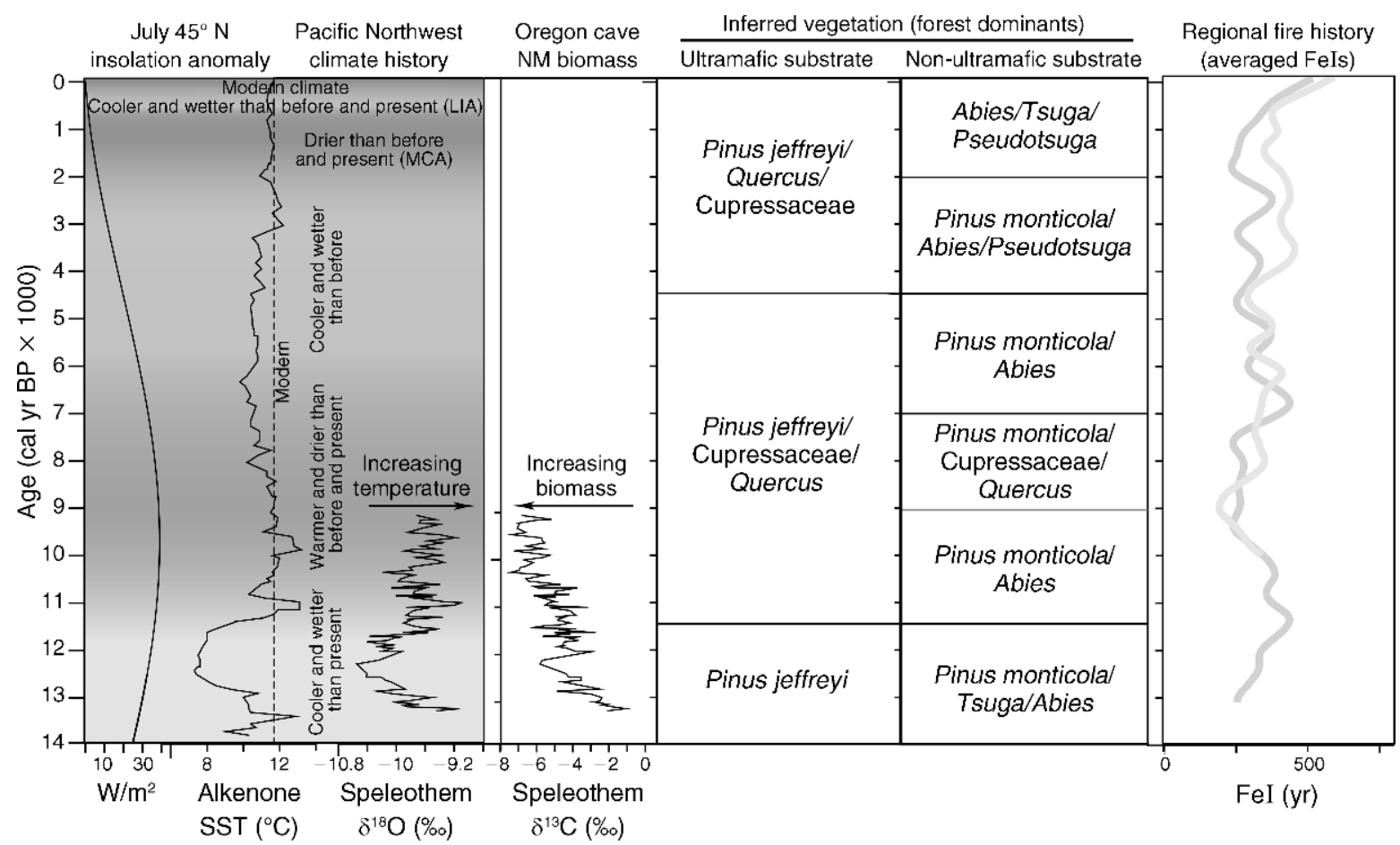

FIG. 4. Climate, vegetation, and fire history (based on pollen and charcoal data) from the Klamath Mountains, July $45^{\circ} \mathrm{N}$ insolation anomaly, Pacific Northwest climate history, and terrestrial biomass production inferred from alkenone-derived seasurface temperatures, speleothem $\delta^{18} \mathrm{O}$-derived temperatures, and $\delta^{13} \mathrm{C}$-derived biomass production; and modeled climate (Bartlein et al. 1998, Barron et al. 2003, Vacco et al. 2005). Key to abbreviations: LIA, Little Ice Age; MCA, Medieval Climatic Anomaly.

high-pressure system and increased continental heating and aridity in the Pacific Northwest (Bartlein et al. 1998). An abrupt warming of $4-5^{\circ} \mathrm{C}$ at $11700 \mathrm{cal}$ yr BP is recorded in the terrestrial speleothem $\delta^{18} \mathrm{O}$-derived temperature record (Vacco et al. 2005) and in the ocean record (Barron et al. 2003), and is associated with an increase in xerophytic species (Cupressaceae and $Q$. vaccinifolia) on both ultramafic and non-ultramafic substrates. In addition, forests on non-ultramafic substrates lost mesophytic conifer species, such as Abies, P. menziesii, and T. mertensiana. All forests experienced compositional changes at $11700 \mathrm{cal} \mathrm{yr} \mathrm{BP.}$

Pollen percentages, between 11000 and $9000 \mathrm{cal} \mathrm{yr}$ BP, of Haploxylon-type Pinus remain as high as in the late-glacial period and then decrease (to $40-50 \%$ at northern sites and $60-70 \%$ at southern sites) between 9000 cal yr BP and present. Pollen percentages of Amelanchier and Q. vaccinifolia were high $(7-10 \%$ at southern sites, $10-20+\%$ at northern sites, respectively) between 9000 and 5000 cal yr BP. Amelanchier, like $Q$. vaccinifolia, does well today in open forests on nonultramafic soils where fires are frequent (Alexander et al. 2007). In addition, low but consistent percentages of Cupressaceae are present after $9000 \mathrm{cal}$ yr BP (2-5\%, with up to $10 \%$ at Sanger Lake). Pollen percentages of Abies between 11000 and $9000 \mathrm{cal}$ yr BP are as high as in the late-glacial period, but decrease significantly (to
$>5 \%$ ) between 9000 and 7000 cal yr BP, and then increase (to 7-10\%) between 7000 and $4500 \mathrm{cal}$ yr BP.

Following the abrupt warming event at $11700 \mathrm{cal} \mathrm{yr}$ BP, SSTs were $1{ }^{\circ} \mathrm{C}$ above modern conditions, between 11000 and $8200 \mathrm{cal} \mathrm{yr} \mathrm{BP}$, and decreased to $2^{\circ} \mathrm{C}$ below modern conditions between 8200 and $3300 \mathrm{cal}$ yr BP (Barron et al. 2003). The changes in percentages of pollen types on non-ultramafic substrates suggest that three distinct changes in vegetation composition and structure occurred between 11000 and $4500 \mathrm{cal}$ yr BP. First, a closed forest of Abies and P. monticola was present during warm and wet conditions between 11000 and $9000 \mathrm{cal} \mathrm{yr}$ BP. Second, the forest changed to an open stand of $P$. monticola/P. lambertiana, Cupressaceae, and $Q$. vaccinifolia/Amelanchier between 9000 and 7000 cal yr BP when conditions were warmer and drier than before and at present. Third, a closed forest of Abies and P. monticola reestablished, as conditions became cooler and wetter between 7000 and $4500 \mathrm{cal} \mathrm{yr}$ BP. The decrease in Abies with warming and drying in the early Holocene and its return in the middle Holocene highlights the species' sensitivity to climate change in the past.

On ultramafic substrates, throughout the early and middle Holocene, percentages of Diploxylon-type Pinus remain low, while those of $Q$. vaccinifolia and Cupressaceae remain high, suggesting that $P$. jeffreyi was less abundant in the forest than in the late-glacial period, but 


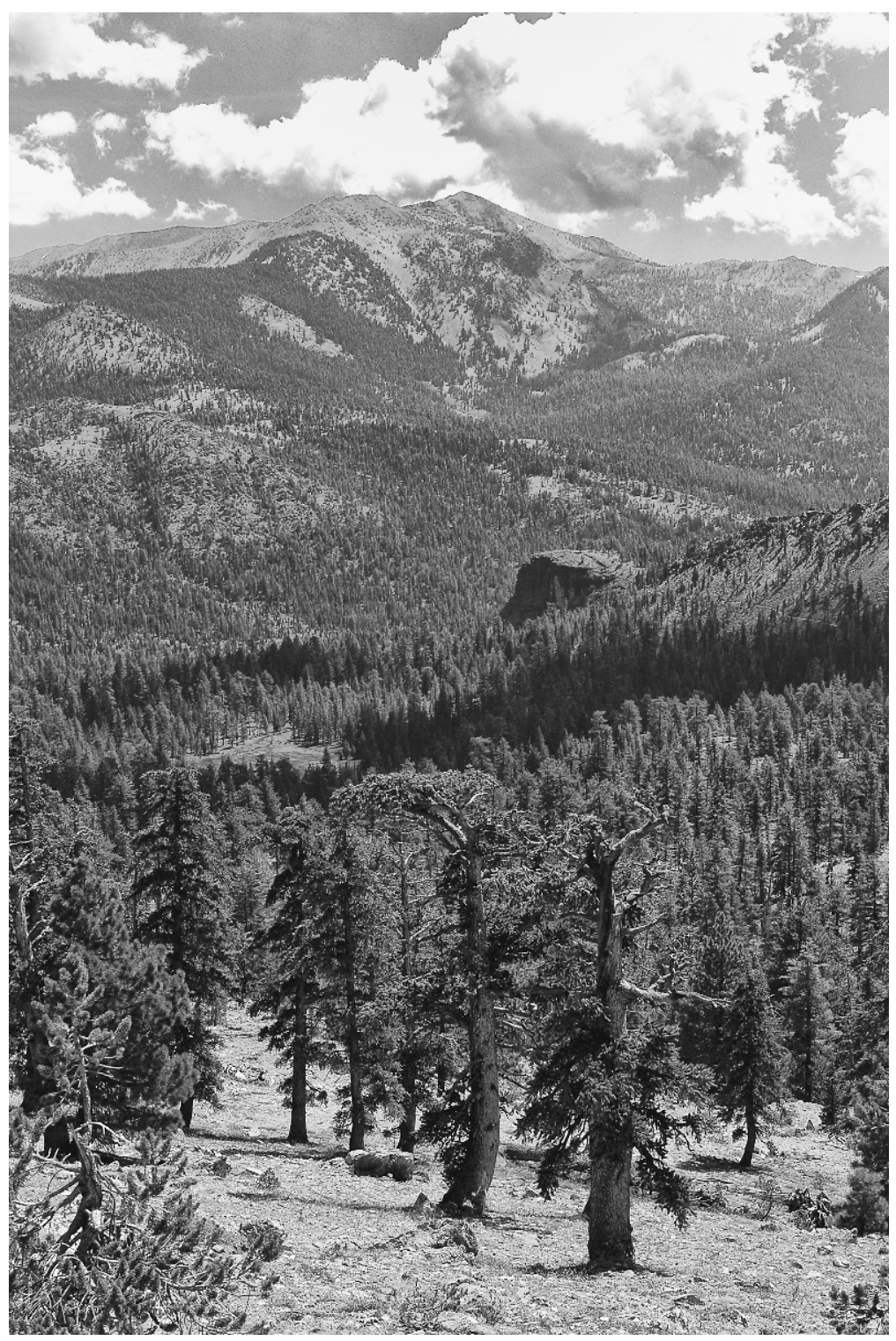

Plate 1. A mélange of rock types and resulting soils in the Klamath Mountains of northern California support a diversity of forest types and plant species. In this photograph, open forests of Pinus jeffreyi, Pinus contorta, Calocedrus decurrens, Abies concolor, and Quercus vaccinifolia (understory) in the Bluff Lake watershed ( $1900 \mathrm{~m}$ elevation) are growing on ultramafic substrates. Photo credit: C. N. Skinner.

it continued to dominate open forests until $5000 \mathrm{cal} \mathrm{yr}$ BP with only minor fluctuations in abundance. Species of Cupressaceae (likely fire-tolerant Calocedrus decurrens and/or Chamaecyparis lawsoniana) were well represented by $11000 \mathrm{cal}$ yr BP during a period of higher fire activity (FeIs of 250-350 years) compared to the late-glacial period. Both species of cedar are firetolerant as mature trees with thick bark (Burns and Honkala 1990). The abundance of Q. vaccinifolia pollen between 11000 and 5000 cal yr BP in forests on ultramafic substrates, suggests an extensive shrub understory. Quercus vaccinifolia is a short-stature shrub that does well in warm dry conditions, has resinous leaves that carry fire from the understory into the forest canopy, and sprouts from the root crown following fire (Burns and Honkala 1990). However, Q. vaccinifolia on ultramafic substrates rarely forms closed, dense chaparral-like stands today, which allows fire-resistant conifer species, such as $P$. jeffreyi and $C$. decurrens, to grow intermittently through the forest. Thus, as early as $11700 \mathrm{cal}$ yr BP, ultramafic substrates supported forests similar to modern open forests of $P$. jeffreyi, cedars, and shrub oak, with only structural changes in vegetation thereafter. In summary, vegetation composition and 
structure on non-ultramafic substrates changed more significantly than on ultramafic soils in the early and middle Holocene.

Short FeIs characterized the early Holocene until $7000 \mathrm{cal}$ yr BP on all substrates, and fire-adapted and fire-tolerant species were abundant in all forests (e.g., $C$. decurrens and/or C. lawsoniana, $Q$. vaccinifolia, and Amelanchier). Between 7000 and $5000 \mathrm{cal} \mathrm{yr} \mathrm{BP,} \mathrm{all}$ substrate types had long FeIs and fire-adapted/tolerant species declined.

Late Holocene (ca. 4500 cal yr BP to present).-At non-ultramafic sites, pollen percentages of Abies increase (to $10-20+\%$ ) and reach peak abundances after 4000 cal yr BP. Pseudotsuga menziesii pollen percentages increase (to 10-15\%) at northern sites and became abundant for the first time $(>5 \%)$ at southern sites after $4500 \mathrm{cal}$ yr BP. Tsuga mertensiana percentages increase to late-glacial abundances (5-10\%) after $2000 \mathrm{cal}$ yr BP, except at Sanger Lake, the lowest elevation site. Pollen percentages of Cupressaceae decrease (to $>2 \%$ ) after $5000 \mathrm{cal}$ yr BP, at all sites except at Sanger Lake where C. lawsoniana forms a riparian forest around the lake margin today (Briles et al. 2008). Quercus vaccinifolia and Amelanchier percentages decline (to $5-10 \%$ at northern sites, and to $5-10 \%$ at southern sites) after ca. 4500 cal yr BP.

Two significant compositional changes in vegetation occurred in the late Holocene at sites with nonultramafic soils in the Klamath Mountains. First, the pollen abundance of Abies species peaked, and $P$. menziesii became more abundant in northern forests; $P$. menziesii also became abundant for the first time in southern forests between 4500 and $2000 \mathrm{cal} \mathrm{yr}$ BP. In addition, species of Cupressaceae were rare or absent, except at Sanger Lake. Second, T. mertensiana became an important component of most high-elevation forests, reaching abundances equivalent to the late-glacial period, and $P$. menziesii reached its peak abundance between $2000 \mathrm{cal} \mathrm{yr} \mathrm{BP}$ and present. At the same time, forests gradually became more closed, particularly within the last 2000 years, indicated by the decrease in shrubs and the peak abundances of Abies.

On ultramafic substrates, pollen percentages of $P$. jeffreyi increase (to 60-70\%), while those of Cupressaceae and Q. vaccinifolia decrease $(>5 \%$ and $>10 \%$, respectively) in the late Holocene. In contrast to the structural and compositional changes observed on nonultramafic substrates, only minor structural changes occurred on ultramafic substrates at the transition to the late Holocene. P. jeffreyi became the dominant species in the forest, and species of Cupressaceae declined in relative abundance. The shrub understory of $Q$. vaccinifolia also decreased significantly suggesting forest structure was comparable to present.

The vegetation on both substrates in the late Holocene is consistent with cooler wetter summers than in the early Holocene, resulting from decreased summer insolation and a weakening northeastern
Pacific subtropical high-pressure system (Bartlein et al. 1998). SSTs were lower after 5000 cal yr BP, and they warmed $1^{\circ} \mathrm{C}$ after $3300 \mathrm{cal}$ yr BP (Barron et al. 2003). Speleothem data are not available for the late Holocene. In addition to the changes in vegetation related to millennial-scale changes in climate, centennial-scale climate fluctuations are associated with significant changes in middle-to-high elevation forests on non-ultramafic substrates in the southeastern Klamath Mountains. For example, when T. mertensiana expanded from 2000 to $1400 \mathrm{cal} \mathrm{yr}$ BP and 600 to 200 cal yr BP, species of Abies were less abundant in the forests. P. menziesii appeared at $4000 \mathrm{cal} \mathrm{yr} \mathrm{BP}$, and declined between 600 and $100 \mathrm{cal}$ yr BP. Species of Abies and P. menziesii were abundant during the warm, relatively dry Medieval Climate Anomaly (1450-600 cal yr BP) detected in tree-ring studies from the region (Graham et al. 2007). In contrast, the greatest abundance of $T$. mertensiana in the late Holocene coincides with the Little Ice Age (600-100 cal yr BP; Taylor 1995, Graham et al. 2007).

Fire activity increased during the late Holocene on non-ultramafic sites with the appearance of $P$. menziesii, a fire-tolerant species (Burns and Honkala 1990). A concurrent decrease in fire activity on ultramafic sites paralleled a decline in fire-adapted species of $Q$. vaccinifolia and species of Cupressaceae. The longest FeIs (500+ years) occurred in the last 500 years at Campbell, Bolan, Sanger, Bluff, and Cedar lakes. In contrast, the last few centuries have featured more fires in the Taylor and Crater watersheds at higher elevations than at the lower sites.

The timing of environmental change as indicated by vegetation change on non-ultramafic substrates in the Klamath Mountains is comparable to that elsewhere in the Pacific Northwest and Sierra Nevada (see Smith and Anderson 1992, Mohr et al. 2000, Briles et al. 2005, Daniels et al. 2005, Beaty and Taylor 2009). However, changes in vegetation and fire activity were not synchronous except at the late-glacial/early-Holocene transition at $11700 \mathrm{cal}$ yr BP, when warm-climate xerophytic species replaced cold-climate mesophytic species and fire activity became more frequent on all substrates. The asynchrony of change at other times may be explained by (1) bottom-up controls (i.e., topography) that alter the effects of large-scale climate changes (e.g., Gavin et al. 2006, Briles et al. 2008), (2) changes in the location of climate boundaries (e.g., Heinrichs et al. 2002, Briles et al. 2005, Brown et al. 2006, Huerta et al. 2009), and (3) edaphic conditions (e.g., Brubaker 1975, Millspaugh et al. 2000; see Results and discussion) that lead to disparities in vegetation sensitivity to large-scale change. This asynchrony suggests that relationships beyond direct impacts of climate on vegetation and fire regimes should be considered in the development of management and conservation plans. 


\section{Question 2: historical factors influencing floral diversity}

The Holocene paleoecology of the Klamath region provides an understanding of how climate change in the past has influenced forests in a geologically complex region, and has important implications for forest management today and in the future. Pollen-based reconstructions of Holocene vegetation history in the Klamath Mountains suggest that substrate variation maintained small-scale spatial differences in forest composition and structure that persisted through the late-glacial period and the Holocene. In general, the vegetation on non-ultramafic substrates responded to past climate variations through elevational adjustments that altered both forest composition and structure. For example, in the late-glacial period, mesic forests of Abies species and Tsuga mertensiana were replaced by more xeric-adapted forests of Pinus monticola and/or $P$. lambertiana, species of Cupressaceae, and Quercus vaccinifolia in the early Holocene under warmer drier conditions than before and at present. Shifts in species composition at the late-glacial/early Holocene transition were equivalent to a $800-1000 \mathrm{~m}$ upward shift in elevation based on modern species distributions (see Briles et al. 2005, 2008), and occurred rapidly in pace with abrupt climate change $\left(\sim 5^{\circ} \mathrm{C}\right.$ warming at $11700 \mathrm{cal}$ yr BP). This change over a 500-year period is comparable with $>200 \mathrm{~m}$ upslope range shifts in trees and shrubs in the last century in California and other mountainous regions (e.g., Beckage et al. 2008, Kelly and Goulden 2008, Kullman and Oberg 2009). Plants were also responsive to short-term variations in climate. For example, the elevation range of T. mertensiana was higher than present during the Medieval Climate Anomaly and lower than present during Little Ice Age cooling. If the past is an analogue for the future, plant species on non-ultramafic substrates will likely respond to projected temperature increases by making elevational range shifts.

The dominant species on ultramafic sites, by contrast, have been less responsive to climate changes during the Holocene, at least so far as can be assessed from pollen and macrofossil assemblages. Species on ultramafic substrates changed in relative abundance, suggesting changes in forest structure. The only significant forest composition change occurred during the rapid $5^{\circ} \mathrm{C}$ temperature increase at $\sim 11700$ cal yr BP that resulted in the addition of $Q$. vaccinifolia and species of Cupressaceae in a forest previously dominated by Pinus jeffreyi and herbs. Within the Holocene, the association of $P$. jeffreyi, species of Cupressaceae, and $Q$. vaccinifolia on ultramafic substrates changed little despite changes from early-Holocene summer warmth and dryness to late-Holocene cooling and increased moisture. Trees and shrubs on ultramafic soils not only exhibit high tolerances of nutrient deficiencies and high concentrations of toxic metals, but they were also able to persist under a range of past climate conditions.
However, the paleorecord lacks the ability to detect many species level responses, in particular those of herbaceous species. Therefore, caution should be used when generalizing these results in consideration of all plant species responses to future climate change.

Fires are an important disturbance agent in the Klamath forests, contributing to the maintenance of high diversity by creating multiple-aged stands of varying size and composition associated with influences of the complex topography (Taylor and Skinner 1998, 2003, Skinner et al. 2006). The charcoal data suggest that fire was important at all sites during the last 15000 years, but that fire activity has varied in response to climate change. The long-term trends in fire activity were broadly similar at all sites until 4000 cal yr BP (Figs. 3 and 4). After 4000 cal yr BP, cooler, wetter conditions resulted in a reduction in evergreen shrub understory and longer FeIs on ultramafic substrates than on nonultramafic terrain. In contrast, the development of closed forests on non-ultramafic substrates in the late Holocene created fuel conditions that favored frequent fires. Fuel structure driven by climate rather than forest composition likely controlled fire regimes in the Klamath Mountains through the Holocene.

This study highlights the importance of substrate variation in creating and maintaining the extraordinary plant diversity and endemism of the Klamath Mountain region. Forests in the Klamath Mountains have responded to Holocene climate changes in at least two ways. First, vegetation on ultramafic terrain, dominated by stress-tolerant species, appears to have been relatively insensitive to past climate variations, insofar as can be detected from the pollen record. The only notable change was a shift from open $P$. jeffreyi parkland to an open mixed forest with Cupressaceae and $Q$. vaccinifolia at $11700 \mathrm{cal}$ yr BP. On more nutrient-rich substrates, plant species responded to climate change through elevational shifts resulting in several episodes of significant change in composition and structure. The combination of long-term persistence of plant communities on ultramafic sites and individualistic range adjustments of forest dominants on non-ultramafic sites may contribute to the high levels of plant diversity and endemism in the Klamath Mountain region.

In conclusion, this study highlights the importance of different ecological responses to climate change resulting from soil-nutrient variations. This relationship should be addressed when predicting future ecosystem responses. Conservation strategies should consider the dramatic changes in vegetation that have occurred on nonultramafic substrates in the past and consider ways to retain sufficient habitat resilience and connectivity to accommodate species adjustments to warming in the future (e.g., Hunter et al. 1988, Whitlock et al. 2004, Froyd and Willis 2009). In ultramafic regions, high levels of endemism and persistence of the dominant species in the past argues for a conservative management approach recognizing the long-term importance of fires 
in these diverse ecosystems and their limited geographical/geological space.

\section{ACKNOWLEDGMENTS}

We thank P. J. Bartlein for discussion of the data and interpretation, T. P. Guilderson for help with the chronology, and P. E. Higuera for statistical advice and age-model development. This research was supported by National Science Foundation Grant ATM-0117160 and USFS PSW Cooperative Agreement, a Lawrence Livermore National Laboratory University Collaborative Research Grant, field research support from Mazamas, Sigma Xi, and graduate research grants from the University of Oregon Department of Geography. Thanks to M. Daniels for providing pollen data from Mumbo Lake, P. Clark and D. Vacco for providing Oregon Cave speleothem data, and J. Barron for ODP 1019 ocean climate data. Thanks also to R. A. Ashmore for his photo-editing of Plate 1. Finally, we thank everyone who helped in the field and laboratory and two anonymous reviewers for suggestions and comments on the manuscript.

\section{Literature Cited}

Agee, J. K. 1993. Fire ecology of Pacific Northwest forests. Island Press, Washington, D.C., USA.

Agee, J. K. 2007. Steward's Fork: a sustainable future for the Klamath Mountains. University of California Press, Berkeley, California, USA.

Alexander, E. B., R. G. Coleman, T. Keeler-Wolfe, and S. P. Harrison. 2007. Serpentine geoecology of western North America. Oxford University Press, New York, New York, USA.

Axelrod, D. I. 1988. Outline history of California vegetation. In M. G. Barbour and J. Major, editors. Terrestrial vegetation of California. California Native Plant Society, Special Publication Number 9. Sacramento, California, USA.

Barbour, M. G., T. Keeler-Wolf, and A. A. Schoenherr. 2007. Terrestrial vegetation of California. Third edition. University of California Press, Berkeley, California, USA.

Barron, J. A., L. Heusser, T. Herbert, and M. Lyle. 2003. Highresolution climate evolution of coastal northern California during the past 16,000 years. Paleoceanography 18:1020-1029.

Bartlein, P. J., K. H. Anderson, P. M. Anderson, M. E. Edwards, C. J. Mock, R. S. Thompson, R. S. Webb, T. Webb III, and C. Whitlock. 1998. Paleoclimate simulations for North America over the past 21,000 years: features of the simulated climate and comparisons with paleoenvironmental data. Quaternary Science Reviews 17:549-585.

Beaty, R. M., and A. H. Taylor. 2009. A 14,000 year sedimentary charcoal record of fire from the northern Sierra Nevada, Lake Tahoe Basin, California, USA. Holocene 19:347-358.

Beckage, B., B. Osborne, C. Pucko, D. G. Gavin, T. Siccama, and T. Perkins. 2008. An upward shift of a forest ecotone during 40 years of warming in the Green Mountains of Vermont, USA. Proceedings of the National Academy of Sciences USA 105:4197-4202.

Bennett, K. D., and K. J. Willis. 2002. Pollen. Pages 5-32 in J. P. Smol, H. J. B. Birks, and W. M. Last, editors. Tracking environmental change using lake sediments. Volume 3 . Terrestrial, algal, and siliceous indicators. Kluwer Academic, Dordrecht, The Netherlands.

Briles, C. 2008. Holocene vegetation and fire history from the floristically diverse Klamath Mountains, northern California, USA. Dissertation. University of Oregon, Eugene, Oregon, USA.

Briles, C., C. Whitlock, and P. J. Bartlein. 2005. Postglacial vegetation, fire and climate history of the Siskiyou Mountains, Oregon, USA. Quaternary Research 64:44-56.

Briles, C., C. Whitlock, and P. J. Bartlein. 2008. Regional and local controls on postglacial vegetation and fire in the
Siskiyou Mountains of northern California and southern Oregon. Palaeogeography, Palaeoclimatology, Palaeoecology 265:159-169.

Brown, K. J., R. J. Fitton, G. Schoups, G. B. Allan, K. A. Wahl, and R. J. Hebda. 2006. Holocene precipitation in the coastal temperate rainforest complex of southern British Columbia, Canada. Quaternary Science Reviews 25:27622779.

Brubaker, L. B. 1975. Postglacial forest patterns associated with till and outwash in northcentral upper Michigan. Quaternary Research 5:499-527.

Burns, R. M., and B. H. Honkala. 1990. Silvics of North America: 1. Conifers; 2. Hardwoods. Agriculture Handbook 654. USDA Forest Service, Washington, D.C., USA.

Cleveland, W. S. 1979. Robust locally weighted regression and smoothing scatterplots. Journal of the American Statistical Association 74:829-836.

Coleman, R. G., and A. R. Kruckeberg. 1999. Geology and plant life of the Klamath-Siskiyou Mountain region. Natural Areas Journal 19:320-341.

Daniels, M. L., R. S. Anderson, and C. Whitlock. 2005. Vegetation and fire history since the Late Pleistocene from the Trinity Mountains, northwestern California, USA. Holocene 15:1062-1071.

DellaSala, D. A., S. R. Reid, T. J. Frest, J. R. Strittholt, and D. M. Olson. 1999. A global perspective on the biodiversity of the Klamath-Siskiyou ecoregion. Natural Areas Journal 19:300-319.

Franklin, J. F., and C. T. Dyrness. 1988. Natural vegetation of Oregon and Washington. OSU Press, Oregon State University, Corvallis, Oregon, USA.

Froyd, C. A., and K. J. Willis. 2009. Emerging issues in biodiversity and conservation management: the need for a palaeoecological perspective. Quaternary Science Reviews 27:1723-1732.

Gavin, D. G., F. S. Hu, K. Lertzman, and P. Corbett. 2006. Weak climatic control of stand-scale fire history during the late Holocene. Ecology 87:1722-1732.

Graham, N. E., M. K. Hughes, C. M. Ammann, K. M. Cobb, M. P. Hoerling, D. J. Kennett, J. P. Kennett, B. Rein, L. Stott, P. E. Wigand, and T. Xu. 2007. Tropical Pacific-midlatitude teleconnections in medieval times. Climate Change 83:241-285.

Grime, J. P., V. K. Brown, K. Thompson, G. J. Masters, S. H. Hillier, I. P. Clarke, A. P. Askew, D. Corker, and J. P. Kielty. 2000. The response of two contrasting limestone grasslands to simulated climate change. Science 289:762-765.

Grime, J. P., J. D. Fridley, A. P. Askew, K. Thompson, J. G. Hodgson, and C. R. Bennett. 2008. Long-term resistance to simulated climate change in an infertile grassland. Proceedings of the National Academy of Sciences USA 105:1002810032.

Grimm, E. C. 1988. Data analysis and display. Pages 43-76 in B. Huntley and T. Webb III editors. Vegetation history. Kluwer Acadenic, Dordrecht, The Netherlands.

Heinrichs, M. L., R. J. Hebda, I. R. Walker, and S. L. Palmer. 2002. Postglacial paleoecology and inferred paleoclimate in the Engelmann spruce-subalpine fir forest of south-central British Columbia, Canada. Palaeogeography, Palaeoclimateology, Palaeoecology 184:347-369.

Hickman, J. C. 1993. The Jepson manual: higher plants in California. University of California Press, Berkeley and Los Angeles, California, USA.

Higuera, P. E., L. B. Brubaker, P. M. Anderson, T. A. Brown, A. T. Kennedy, and F. S. Hu. 2008. Frequent fires in ancient shrub tundra: implications of Paleorecords for Arctic environmental change. PLoS ONE 3:e0001744.

Huerta, M., C. Whitlock, and J. Yale. 2009. Holocene vegetation-fire-climate linkages in Northern Yellowstone National Park, USA. Palaeogeography, Palaeoclimatology, Palaeoecology 271:170-181. 
Hunter, M. L., G. L. Jacobson, and T. Webb. 1988. Paleoecology and the coarse-filter approach to maintaining biological diversity. Conservation Biology 2:375-385.

Irwin, W. P. 1981. Tectonic accretion of the Klamath Mountains. Pages 29-49 in W. G. Ernst, editor. The geotectonic development of California. Prentice-Hall, Englewood Cliffs, New Jersey, USA.

Jackson, S. T., J. T. Overpeck, T. Webb III, S. E. Keattch, and K. H. Anderson. 1997. Mapped plant macrofossil and pollen records of Late Quaternary vegetation change in eastern North America. Quaternary Science Reviews 16:1-70.

Jimerson, T. M., L. D. Hoover, E. A. McGee, G. DeNitto, and R. M. Creasy. 1995. A field guide to serpentine plant associations and sensitive plants in northwestern California. USDA Forest Service Pacific Southwest Region Publication R5-ECOL-TP-006.

Kelly, A. E., and M. L. Goulden. 2008. Rapid shifts in plant distribution with recent climate change. Proceedings of the National Academy of Sciences USA 105:11823-11826.

Kruckeberg, A. R. 1984. California serpentines: flora, vegetation, geology, and management problems. University of California Publications in Botany 78:1-180.

Kruckeberg, A. R. 2002. Geology and plant life: the effects of landforms and rock types on plants. University of Washington Press, Seattle, Washington, USA.

Kullman, L., and L. Oberg. 2009. Post-Little Ice Age tree line rise and climate warming in the Swedish Scandes: a landscape ecological perspective. Journal of Ecology 97:415-429.

Marlon, J., P. J. Bartlein, and C. Whitlock. 2006. Fire-fuelclimate linkages in the northwestern United States during the Holocene. Holocene 16:1059-1071.

Millspaugh, S. H., C. Whitlock, and P. J. Bartlein. 2000. Variations in fire frequency and climate over the last 17,000 years in central Yellowstone National Park. Geology 28:211214.

Mohr, J. A., C. Whitlock, and C. N. Skinner. 2000. Postglacial vegetation and fire history, Eastern Klamath Mountains, California. Holocene 10:587-601.

Oswald, W. W., L. B. Brubaker, F. S. Hu, and G. W. Kling. 2003. Holocene pollen records from the central Arctic Foothills, northern Alaska: testing the role of substrate in the response of tundra to climate change. Journal of Ecology 91:1034-1048.

Proctor, J. 1990. Magnesium as a toxic element. Nature 227:742-743.

Reimer, P. J., et al. 2004. IntCa104 terrestrial radiocarbon age calibration, 0-26 cal kyr BP. Radiocarbon 46:1029-1058.

Ricketts, T., E. Dinerstein, D. M. Olson, C. J. Loucks, W. M. Eichbaum, D. A. DellaSala, K. C. Kavanagh, P. Hedao, P. T. Hurley, K. M. Carney, R. A. Abell, and S. Walters. 1999. A conservation assessment of the terrestrial ecoregions of North America, volume I: the United States and Canada. Island Press, Washington, D.C., USA.
Sawyer, J. O., and D. A. Thornburgh. 1988. Montane and subalpine vegetation of the Klamath Mountains. Pages 699732 in M. G. Barbour and J. Major, editors. Terrestrial vegetation of California. Special Publication Number 9, California Native Plant Society, Sacramento, California, USA.

Skinner, C. N. 2003. Fire regimes of upper montane and subalpine glacial basins in the Klamath Mountains of northern California. Tall Timbers Research Station Miscellaneous Publication 13:145-151.

Skinner, C. N., A. H. Taylor, and J. K. Agee. 2006. Fire in the Klamath Mountains bioregion. Pages 170-194 in N. S. Sugihara, J. W. van Wagtendonk, J. Fites-Kaufmann, K. Shaffer, and A. Thode, editors. Fire in California ecosystems. University of California Press, Berkeley, California, USA.

Smith, S. J., and R. S. Anderson. 1992. Late Wisconsin paleoecologic record from Swamp Lake, Yosemite National Park, California. Quaternary Research 38:91-102.

Stuiver, M., P. J. Reimer, and R. W. Reimer. 2005. CALIB 5.0. $\langle$ http://calib.qub.ac.uk/calib/〉

Taylor, A. H. 1995. Forest expansion and climate change in the mountain hemlock (Tsuga mertensiana) zone, Lassen Volcanic National Park, California, U.S.A. Arctic and Alpine Research 27:207-216.

Taylor, A. H., and C. N. Skinner. 1998. Fire history and landscape dynamics in a late-successional reserve, Klamath Mountains, California, USA. Forest Ecology and Management 111:285-301.

Taylor, A. H., and C. N. Skinner. 2003. Spatial patterns and controls on historical fire regimes and forest structure in the Klamath Mountains. Ecological Applications 13:704-719.

Vacco, D. A., P. U. Clark, A. C. Mix, H. Cheng, and R. L. Edwards. 2005. A speleothem record of Younger Dryas cooling, Klamath Mountains, Oregon, USA. Quaternary Research 64:249-256.

Whitlock, C. 1993. Postglacial vegetation and climate of Grand Teton and southern Yellowstone National Parks. Ecological Monographs 63:173-198.

Whitlock, C., and C. P. S. Larsen. 2002. Charcoal as a fire proxy. Pages 75-97 in J. P. Smol, H. J. B. Birks, and W. M. Last, editors. Tracking environmental change using lake sediments. Volume 3. Terrestrial, algal, and siliceous indicators. Kluwer Academic, Dordrecht, The Netherlands.

Whitlock, C., C. N. Skinner, P. J. Bartlein, T. Minckley, and J. A. Mohr. 2004. Comparison of charcoal and tree-ring records of recent fires in the eastern Klamath Mountains. Canadian Journal of Forest Research 34:2110-2121.

Whittaker, R. H. 1960. Vegetation of the Siskiyou Mountains, Oregon and California. Ecological Monographs 30:279-338.

Wright, H. E., Jr., D. H. Mann, and P. H. Glaser. 1983. Piston cores for peat and lake sediments. Ecology 65:657-659.

\section{APPENDIX A}

Detailed site descriptions for lakes with vegetation and fire histories in the Klamath Mountains (Ecological Archives E092-052A1).

\section{APPENDIX B}

Age chronologies based on ${ }^{14} \mathrm{C}$ AMS and ${ }^{210} \mathrm{~Pb}$ dates for unpublished and published data for Klamath Mountain sites (Ecological Archives E092-052-A2).

\section{APPENDIX C}

Age vs. depth curves and deposition times based on radiocarbon and ${ }^{210} \mathrm{~Pb}$ dates and tephrochronology (Ecological Archives E092-052-A3). 